\title{
Evaluation of coastal vulnerability to flooding: comparison of two different methodologies adopted by the Emilia-Romagna region (Italy)
}

\author{
L. Perini ${ }^{1}$, L. Calabrese ${ }^{1}$, G. Salerno ${ }^{1}$, P. Ciavola ${ }^{2}$, and C. Armaroli ${ }^{2}$ \\ ${ }^{1}$ Geological, Seismic and Soil Service of the Emilia-Romagna Region, viale della Fiera 8, 40127 Bologna, Italy \\ ${ }^{2}$ Department of Physics and Earth Sciences, University of Ferrara, via Saragat 1, 44122 Ferrara, Italy
}

Correspondence to: C. Armaroli (clara.armaroli@unife.it)

Received: 14 March 2015 - Published in Nat. Hazards Earth Syst. Sci. Discuss.: 7 July 2015

Revised: 30 November 2015 - Accepted: 2 December 2015 - Published: 19 January 2016

\begin{abstract}
This paper aims at presenting and comparing two methodologies adopted by the Emilia-Romagna region, northern Italy, to evaluate coastal vulnerability and to produce hazard and risk maps for coastal floods, in the framework of the EU Floods Directive. The first approach was adopted before the directive had been issued. Three scenarios of damage were designed (1-, 10-, 100-year return periods), produced by the concurrent occurrence of a storm, high surge levels and high-water spring tidal levels. Wave heights were used to calculate run-up values along 187 equally spaced profiles, and these were added to the tidal and atmospheric water level contributions. The result is a list of 10 vulnerability typologies. To satisfy the requirements of the directive, the Geological, Seismic and Soil Service (SGSS) recently implemented a different methodology that considers three scenarios (10-, 100- and > 100-year return periods) in terms of wave setup (not including run-up) plus the contribution of surge levels as well as the occurrence of high-water springs. The flooded area extension is determined by a series of computations that are part of a model built into $\operatorname{ArcGIS}^{\circledR}$. The model uses as input a high-resolution lidar DEM that is then processed using a least-path cost analysis. Inundation maps are then overlapped with land use maps to produce risk maps. The qualitative validation and the comparison between the two methods are also presented, showing a positive agreement.
\end{abstract}

\section{Introduction}

Climate change, sea level rise and their impact on humans and the environment are key issues that were, and still are, addressed at European level by many EU-funded projects within the 7th European Union Research Framework (Quevauviller, 2011). Likewise, in the newly created H2020 EU research framework, a large investment will be made in improving the understanding of the risk posed to the EU population and economy by climate-induced hazards. In the framework of the EU Floods Directive, the SPRC approach (Source-Pathway-Receptor-Consequence; Jimenez et al., 2008; Zanuttigh, 2011) is frequently used to evaluate flood issues. The storm component (source) is put in relation to the receptor (the coastal area) through numerical modelling that is able to evaluate the extent of flooding (Barredo et al., 2008; Zanuttigh et al., 2011; Wadey et al., 2012; Villatoro et al., 2013). This includes the evaluation of defence failure and breaching (Wadey et al., 2012; Villatoro et al., 2013), the impact of the overflow of freshwater canals (Villatoro et al., 2013), and the importance of flow through underground pipes (Sto. Domingo et al., 2010). The main challenge when actually drawing flood hazard maps is how to couple information on the total water level components (i.e. waves, runup, surge, tide, sea level rise) with terrain characteristics of the coastal area and hinterland zones. The need for highresolution digital elevation models (DEMs), when available, is agreed among experts worldwide and also included in official flood assessment guidelines of different countries at EU and non-EU level (e.g. EXCIMAP, 2007; LAWA - German Working Group on Water Issues of the Federal States and 
the Federal Government, 2010; CREW - Centre of Expertise for Waters, 2012; NOAA, 2012). DEMs are used to define which areas are flood-prone, as they give detailed information on terrain elevations and location of different structures and infrastructures. A main challenge for researchers and practitioners is also to choose representative storm conditions, through an analysis of measured time series of waves and water levels, in order to generate maximum water level scenarios (among others Salecker et al., 2011; Corbella and Stretch, 2012; Villatoro et al., 2013), with different return periods, that are representative of what might occur in the future. As measured time series are often limited in temporal extension and only available for recent decades, longer-term assessment can be made using hindcasting from global reanalysis databases (Harley et al., 2010).

The projection of water levels landward and, consequently, the computation of flood extension can be assessed through 2-D and 3-D numerical models such as MIKE 21 and MIKE FLOOD (Sto. Domingo et al., 2010; Zanuttigh et al.; 2011; Villatoro et al., 2013), LISFLOOD-FP (Barredo et al., 2008; Purvis et al., 2008; Wadey et al., 2012), and ADCIRC (Colle et al., 2008; Lin et al., 2010), ANUGA (Van Drie et al., 2010) in order to evaluate how far the marine water will flow landward, its water depths and its flow velocities. Nevertheless, to lower the computational demand and to apply models to larger coastal stretches, low-resolution DEMs are often created or, alternatively, the resolution of available DEMs is lowered. This leads to a reduction in the accuracy of flood maps, especially where the coast is characterised by a large number of vulnerable features concentrated within a limited portion of territory and, consequently, when a detailed analysis is required. In fact, the confidence in the identification of vulnerable land is much improved when the assessment is derived from higher-resolution DEMs (Gesch, 2009). If larger coastal stretches have to be analysed (spatial scale of hundreds of kilometres), a methodology commonly adopted is the so-called bathtub method. The method consists in comparing water levels to terrain elevations, and where the terrain elevation is lower than or equal to the computed water level, the area is identified as being flood-prone. The methodology has proved to be inaccurate because it overpredicts the extension of flooded areas and does not take into account the hydrological connectivity between different areas (Poulter and Halpin, 2008; Gesch, 2009; Murdukhayeva et al., 2013). Poulter and Halpin (2008) found that DEM horizontal resolution and hydrological connectivity have a significant influence on the extent and duration of flooding. Indeed, the authors used a methodology that incorporates the hydrological connectivity between grid cells into the bathtub method: only cells that have a connection with the open sea and with inundated nearby cells are considered flood-prone.

Directive 2007/60/EC was issued at the end of 2007. It is normally identified as the Floods Directive and includes regulations to evaluate and manage flood risks both from rivers and along EU coastlines. To satisfy the requirements of the
Floods Directive, the states of the European Union have implemented different methodologies (De Moel et al., 2009). Some countries have adopted a national approach, others a regional approach, and in some cases even a municipalitylevel approach was chosen.

The Emilia-Romagna coastline, Italy, facing the northern Adriatic Sea, is affected by storms that cause extensive damages. The coast of the region has large portions of the territory below mean sea level and is highly urbanised. Consequently, an evaluation of the vulnerability of the coastal area is an urgent matter.

The current paper aims at presenting in detail the methodology adopted at regional level in Emilia-Romagna to satisfy the requirements of the Floods Directive. The directive was implemented into the Italian legislation through Legislative Decree 49/2010. The hazard maps are presented here in comparison with another approach that produced vulnerability maps along profile lines (hereafter referred to as "VaPL") and which was adopted locally before the directive had been issued. The VaPL approach has already been presented in several refereed papers and conference proceedings (Ciavola et al., 2008; Armaroli et al., 2009a, b, 2012a, b, 2013; Armaroli and Perini, 2012). Thus, only a brief summary is outlined in the current paper in the Methods and Results sections. The Geological, Seismic and Soil Service (SGSS) has produced a very large database of storm characteristics, locations of flooding and damages, their costs, etc. (up to 2010 - Perini et al., 2011; up to present - online storm catalogue "in_Storm", http://ambiente.regione.emilia-romagna. it/geologia/archivio_pdf/pubblicazioni/in_storm.pdf). Both methodologies were qualitatively tested using data collected after major storms, and the validation is also described hereafter. Finally, the results of the two approaches are compared.

\section{Field site description}

The coast of the Emilia-Romagna region is composed of sandy beaches stretching over $130 \mathrm{~km}$, facing the northern Adriatic Sea. The area is characterised by low elevations above mean sea level (m.s.l.) and a high level of human occupation. If the coastal topography and altimetry are taken into account, the coastline can be divided into two sectors (Regione Emilia-Romagna, 2010; Fig. 1). (i) The northern one, which comprises the Ferrara and Ravenna provinces, is characterised by wide and low-elevation coastal plains, composed of cultivated fields, wetlands and marshes, most of them reclaimed, that show elevations that are generally below mean sea level and can reach minimum values of $-2 /-3 \mathrm{~m}$. The low-elevation areas are separated from the sea by dune ridges, both old and active, that protect the hinterland from flooding. The northern part of the coast includes the only remaining dune fields of the region, which represent almost $40 \%$ of this sector. (ii) The southern portion includes the Forlì-Cesena and Rimini provinces (Fig. 1) and is charac- 


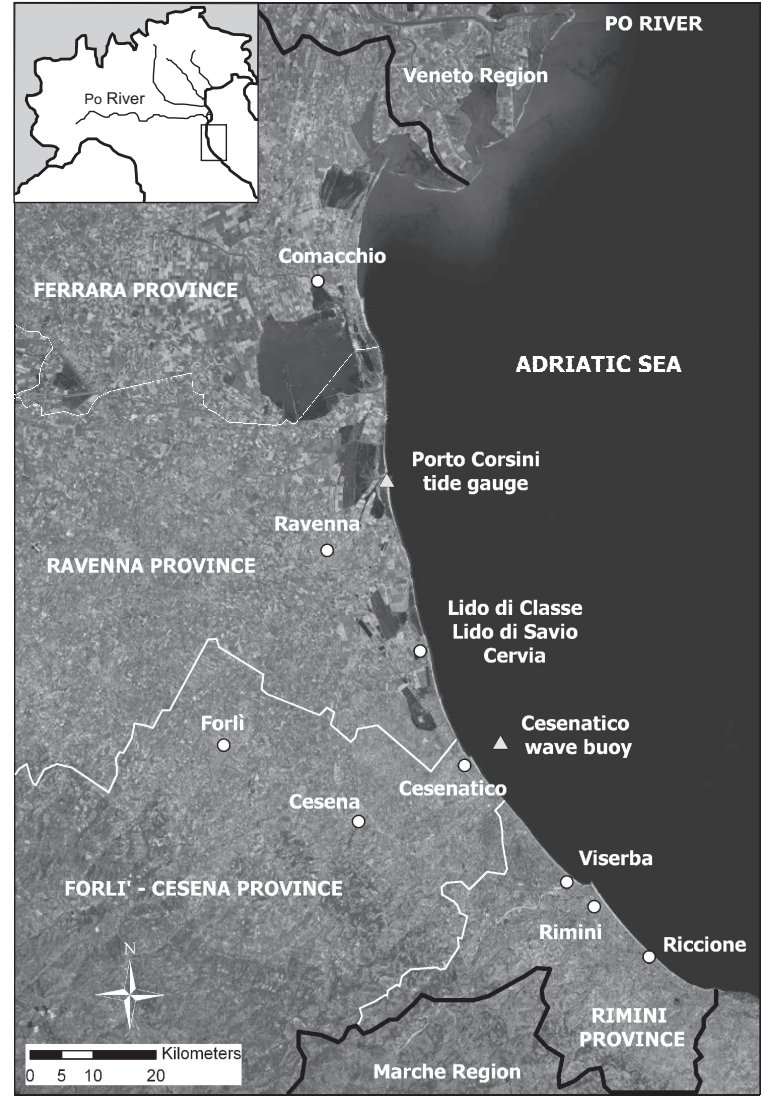

Figure 1. The Emilia-Romagna coastal area, northern Italy: location of places addressed in the text, as well as main cities and coastal towns.

terised by a narrow coastal corridor where active and semistabilised dunes disappeared and the old dune ridges occupy a narrow and short strip of the hinterland. Elevations are generally above mean sea level (mean values are between 2 and $3 \mathrm{~m}$ ). The index of occupation, defined as the length of urbanised coast divided by the length of the coast, is equal to 1.

The coastal zone experienced intense exploitation that started after World War II and had its peak around the 1970s, when urban settlements grew and tourism became one of the most important economic activities of the region. The consequence of this development was the destruction of coastal dunes, mainly by using sand for concrete production. Buildings, roads and other facilities replaced dunes and natural environments. Furthermore, the increase in population and industrial activities along the coast enhanced groundwater extraction, with the consequence of increasing land subsidence. Where this was coincident with subsidence caused by gas extraction, it locally reached peaks of $2 \mathrm{~cm}_{\text {year }}{ }^{-1}$ (at the coast near Ravenna; Teatini et al., 2005). Protected beaches currently represent almost the $60 \%$ of the coastline (groynes, breakwaters, submerged barriers, artificial embankments, dykes and rubble-mound slopes). Starting from the end of 1990s, large nourishment projects were carried out using sediments obtained from offshore sand deposits, quarries and alongshore deposits. The latter are generated by the presence of groynes, jetties and ports that interrupt the alongshore sediment transport at many points along the coast.

The wave climate of the coast has low energy ( $91 \%$ of Hs below $1.25 \mathrm{~m}$; Ciavola et al., 2007). The area is microtidal: the spring tidal range is $80-90 \mathrm{~cm}$, and the neap range is $30-40 \mathrm{~cm}$ (Idroser, 1996). The main storm directions are from E-NE (bora wind) and SE (scirocco wind). Surge levels are an important element controlling total water levels measured during storms (Masina and Ciavola, 2011). The highest surge levels are generated by southeasterly winds that favour water piling in the northern Adriatic Sea. When the famous acqua alta (high water) occurs in Venice, which is located around $150 \mathrm{~km}$ to the north of the study area, the Emilia-Romagna coast suffers from the same phenomenon, which can cause extensive erosion and inundation if associated with storm waves (Armaroli et al., 2012a). Masina and Ciavola (2011) found that the 1-in-10year return period surge is close to $1 \mathrm{~m}$ and thus that it can double the tidal range. Storms can be energetic (Table 1) with the maximum-recorded wave event having a significant wave height of $5.65 \mathrm{~m}$ (Ciavola et al., 2007). Armaroli et al. (2012a) identified critical storm thresholds that can generate floods, damage to structures and beach erosion along built-up coastal stretches: $\mathrm{Hs}=1.5 \mathrm{~m}$ and water level (surge level + tide $)=0.85 \mathrm{~m}$. Wave data are registered by the Datawell Directional Waverider of ARPA-SIMC (the regional hydrometeorological service) located near Cesenatico and tides are registered by the gauge of the ISPRA RMN (National Institute for Research and Environment Protection - National Tide Gauging Network) network located in Porto Corsini, near Ravenna (Fig. 1).

\section{Methods}

The following methodological section is divided into two subsections. Firstly, the methodology that considers coastal vulnerability along profile lines is summarised briefly. In the second part, hazard and risk maps issued by the region are presented in detail.

\subsection{Vulnerability maps along profile lines}

In 2006, the SGSS of the Emilia-Romagna region started an analysis of the probable impact of marine storms along the coastline. The adopted methodology was designed to calculate maximum water levels along equally spaced cross-shore transects (almost $500 \mathrm{~m}$ ) extracted from a DTM and DSM (digital terrain and digital surface models) produced using a 
Table 1. Storm conditions used to design the three worst-case scenarios along profile lines.

\begin{tabular}{|c|c|c|c|c|c|c|}
\hline \multirow[t]{2}{*}{ Return period } & \multicolumn{2}{|c|}{$\mathrm{T} 1$} & \multicolumn{2}{|c|}{$\mathrm{T} 10$} & \multicolumn{2}{|c|}{ T100 } \\
\hline & Hs (m) & Ts (s) & Hs (m) & Ts (s) & Hs (m) & Ts (s) \\
\hline Wave & 3.3 & 7.7 & 4.7 & 8.9 & 5.9 & 9.9 \\
\hline Surge (m) & \multicolumn{2}{|c|}{0.85} & \multicolumn{2}{|c|}{1.039} & \multicolumn{2}{|c|}{1.28} \\
\hline Tide (m) & \multicolumn{2}{|c|}{0.45} & \multicolumn{2}{|c|}{0.45} & \multicolumn{2}{|c|}{0.45} \\
\hline Total water level (m) & \multicolumn{2}{|c|}{1.3} & \multicolumn{2}{|c|}{1.489} & \multicolumn{2}{|c|}{1.73} \\
\hline
\end{tabular}

2004 lidar flight. The profiles extended from the intertidal area up to the rear beach, including the rear dune area, along natural coastal stretches, and including the first line of structures located on/close to the beach along urbanised zones. The profiles are cross-shore transects that are part of a network that has been monitored by the regional environment agency since the early 1990s. The maximum water levels were computed for three return period storms (1-in-1-, 1-in10- and 1-in-100-year) as the sum of run-up, surge and high mean spring tide in order to consider a worst-case scenario (Table 1).

The variability in natural and developed coastal environments located along the coastline was taken into account. Along areas characterised by the presence of dunes, a specific indicator was designed (dune stability factor; Armaroli et al., 2012a; Ciavola et al., 2014). Where the coast is protected by semi-submerged and emerged shore-parallel breakwaters, the wave transmission coefficient was calculated to obtain a representative wave height in very shallow water (Armaroli et al., 2009b). Lastly, coastal tracts protected by rubble-mound slopes were studied using appropriate run-up formulas (Armaroli and Perini, 2012). The general computational protocol was structured as follows:

1. Extraction of profile lines along the whole regional coastline, from the lidar data set (DSM and DTM).

2. Selection of wave characteristics, surge and tide elevations from the literature, for the three considered return periods (Table 1; Idroser, 1996; Yu et al., 1998).

3. Computation of beach slope values along each profile line.

4. Computation of run-up levels using the Holman (1986) formula, modified by Komar (1998) to include setup.

5. Sum of the different components to calculate the maximum water levels.

6. Comparison of the obtained levels with the elevation of the beach and of facilities (beach huts, bars, roads, etc.) located along each profile line.

7. Design of 10 typologies of impact to create vulnerability maps.
The maps were validated through the comparison between the vulnerability typologies identified along the coastline and the observed impacts of significant storms. In the Results section of the current paper, the comparison with a recent storm (10 March 2010) is presented as a validation exercise. A second validation was carried out after a strong event occurred during the night of 31 October-1 November 2012, locally known as the "Halloween storm" (Harley et al., 2015).

\subsection{Hazard and risk maps}

To produce hazard and risk maps at a regional scale, the SGSS of the Emilia-Romagna region implemented a methodology that was calibrated with the information available in the catalogue of historical storm (Perini et al., 2011; "In_Storm" online catalogue) and also with the terrain characteristics of the coastal stretch. The methodology is based on five steps:

1. Selection of storm information and computation of total water levels for three return period events (1-in-10-, 1in-100- and >1-in-100-year).

2. Compilation of a model into ArcGIS ${ }^{\circledR}$ (ModelBuilder tool) to elaborate input data and produce hazard maps; critical evaluation and refinement of the outputs.

3. Overlap of the hazard maps with land use maps to create risk maps.

4. Identification of low-lying locations (hereafter referred to as "passages") that act as pathways for the water, leading to the inundation of rear areas.

5. Qualitative comparison of the obtained hazard maps with the extension of inundated areas measured after recent storms.

The model input DTM (digital terrain model) is represented by the 2008 lidar national flight $(2 \mathrm{~m} \times 2 \mathrm{~m}$ resolution; vertical precision $=0.2 \mathrm{~m}$ ) undertaken by the Italian Ministry for the Environment (http://www.pcn.minambiente.it/GN/en/ projects/not-ordinary-plan-of-remote-sensing). The DTM resolution was not reduced, because a very accurate analysis of the terrain's characteristics was needed. The total water level (TWL, Table 2) was computed as the sum of different variables extracted from the literature in order to design 
Table 2. Total water level values of each scenario. Comments on RP $>100$ can be found in the text.

\begin{tabular}{lrrrrr}
\hline Scenario & $\begin{array}{r}\text { Return period } \\
(\mathrm{yr})\end{array}$ & $\begin{array}{r}\text { Storm surge } \\
(\mathrm{m})\end{array}$ & $\begin{array}{r}\text { High spring tide } \\
(\mathrm{m})\end{array}$ & $\begin{array}{r}\text { Wave setup } \\
(\mathrm{m})\end{array}$ & $\begin{array}{r}\text { Total water level } \\
(\mathrm{m})\end{array}$ \\
\hline Frequent (P3) & 10 & 0.79 & 0.40 & 0.30 & 1.49 \\
Low frequency (P2) & 100 & 1.02 & 0.40 & 0.39 & 1.81 \\
Rare (P1) & $>100$ & - & - & - & 2.5 \\
\hline
\end{tabular}

three worst-case scenarios: surge levels (Masina and Ciavola, 2011), wave setup elevations (Decouttere et al., 1998) and the mean astronomical high spring tidal level (Idroser, 1996). Wave setup represents the mean value along the whole regional coastline computed with the LITPACK model of wave time series generated with WAM (Wave Model) for different directions, assuming an average bottom slope of 1/50 (Decouttere et al., 1998). WAM results at a depth of $20 \mathrm{~m}$ were back-tracked into deep-water conditions (i.e. $100 \mathrm{~m}$ ) through inverse refraction and shoaling. The computations were performed for irregular waves. The TWL return period value exceeding 100 years (Table 2) was chosen based on analyses of historical storms (1966 flooding; Perini et al., 2011) and extreme events included into the first coastal plan issued by the Emilia-Romagna region (Idroser, 1982). Furthermore, the choice of the $2.5 \mathrm{~m}$ elevation is justified by the fact that local practitioners use it to design coastal protection structures.

The methodology does not include run-up levels, the effect of land subsidence and the presence of temporary flood protection built on beaches during the winter season (the socalled "winter dunes"; Harley and Ciavola, 2013). The elements listed above were not considered in the analysis because the region wanted to implement a simple and quickly replicable methodology, while the inclusion of the abovementioned variables and features would have led to more complex and time-consuming procedures (Sekovski et al., 2015).

Once TWLs were computed, they were compared to the elevation values of the 2008 high-resolution DTM, using the bathtub method. Overall the procedure seemed to overestimate the extension of flooded areas, as the elevation of the backshore is low, especially in the northern part of the region. Thus, an attenuation artifice was introduced as a proxy for bed friction and infiltration over distance from the shoreline, projecting the water surface inland over a sloping plane with an inclination corresponding to a cotangent of 0.002 (Sekovski et al., 2015). However, the resulting hazard maps were still not consistent with field observations and historical information (Sekovski et al., 2015). Hence, the Cost Distance tool of ArcGIS ${ }^{\circledR}$ was applied (http://help.arcgis.com/en/arcgisdesktop/10.0/ help/index.html\#//009z00000018000000.htm) and a new model was built into $\operatorname{ArcGIS}^{\circledR}$ to re-elaborate the data (Fig. 2).
The DTM was clipped at a landward boundary that corresponded to the flooding extension resulting once the attenuation artifice was applied in order to be sure that all the potentially flood-prone zones were included. First, the highresolution DTM elevations were compared to the TWL of each scenario, one at a time, to exclude zones that have an elevation higher than the potentially maximum water level. The output was then a reclassified grid (Grid_1 in Fig. 2) where zones with an elevation $>$ TWL were assigned an arbitrary value of 999 and the others (elevation $<$ TWL) were assigned a value of 1 . These fictitious values were necessary to exclude from successive steps those areas that, given their elevation above TWL, are not flood-prone. Then, the Cost Distance tool was applied to assign to each cell of the new grid a value that indicates its least horizontal distance from the $0.0 \mathrm{~m}$ a.m.s.l. contour line extracted from the 2008 lidar grid (the origin), in terms of "paths" (i.e. paths that avoid or favour the water movement landward) and not in terms of Euclidean distance (Sekovski et al., 2015). The distance value of each cell of the grid was weighted through the arbitrary values (999 and 1) given to Grid_1 (Fig. 2); thus cells equal to 1 were assigned a value that equalled the distance computed with the tool, and cells equal to 999 were assigned a very large value. The output was a second grid (Grid_2 in Fig. 2). The next step multiplies the distance values of each cell of Grid_2 by the attenuation angle described above (cotangent $=0.002$ ) to convert distance values into elevations. The output was a third grid (Grid_3 in Fig. 2) whose cells' elevations represented the minimum water level needed to produce flooding. The successive step takes as input one TWL at a time that is subtracted to Grid_3 elevations. The output is a grid (Grid_4 in Fig. 2) where every cell has an elevation assigned that is positive, negative or zero. Positive and zero values correspond to cells that are flood-prone (cells that were assigned value $=1$ in Grid_1), and negative numbers represent areas that are safe from inundation (cells that were assigned the arbitrary 999 value in Grid_1). The last step consisted in comparing the lidar DTM to Grid_4. If Grid_4 elevations are greater or equal than DTM heights, cell by cell, then the area is flood-prone. The final output was a grid (Grid_5) that represented the extent of flood-prone areas for each scenario. Finally, other steps were completed outside the model: (i) the conversion of Grid_5 into a polygon feature, (ii) the deletion of non-flood-prone polygons, and (iii) the deletion of isolated areas not connected with the 


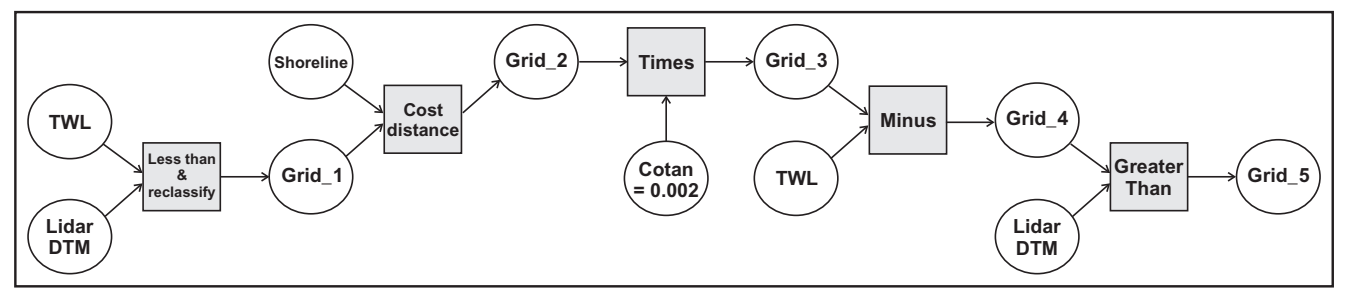

Figure 2. Flow diagram of the ArcGIS ${ }^{\circledR}$ model: input and output are represented by ellipsoids; the ArcGIS ${ }^{\circledR}$ tools (Less Than, Reclassify, Cost Distance, Times, Minus, Greater Than) are represented by rectangles.

shoreline. The final output was a polygon feature that represented the extent of flood-prone zones for each scenario. The polygon features corresponding to each analysed return period (RP) were named, according to Article 6 of the Floods Directive, P1 ("rare"; RP > 100 years), P2 ("not frequent"; $\mathrm{RP}=100$ years) and $\mathrm{P} 3$ ("frequent"; $\mathrm{RP}=10$ years) (Table 2; Sekovski et al., 2015).

At regional and national level, it was decided that risk maps would be produced based on land use maps developed by the regional authorities. The location of sensitive elements such as hospitals, key infrastructures, schools, and number of inhabitants was also taken into account. As depth-damage curves for the Italian territory are not available for marine floods, the vulnerability of each type of land use was classified using a unit scale from 1 to 4 according to its exposure (i.e. from D1 (low) to D4 (high)). The damage classification was prepared by the SGSS in order to take into account specific characteristics and different uses of the territory located close to the coast. The regional and national authorities decided to consider as highly exposed those areas occupied by settlements, sensitive constructions and human activities (tertiary activities, agriculture, etc.), because human-related direct and indirect losses are considered the most critical issue. For this reason, infrastructures such as urban areas, industrial zones, ports, water supply and electricity networks were given the maximum value (D4), while the beach, active dunes, etc. (i.e. areas without human occupation) were considered less exposed and given a D1 value. A matrix that combines the three designed scenarios and the exposure values was built and risk classes, from R4 (high risk) to R1 (low risk), were derived from the linkage between the two inputs (Table 3).

The hazard maps were validated using several sources: (i) comparison between the hazard maps and the extension of inundated areas measured after significant storms and (ii) consultation with local experts who have long-term experience in coastal issues to collect their suggestions and opinions on the reliability of the obtained maps. In the Results section, only the first validation procedure is presented. Finally, a comparison was made between the results of the hazard maps and the typologies of impact derived from the vulnerability cartography along profile lines. The compared
Table 3. Risk classes obtained through the matching between hazard scenarios and values given to different land use categories.

\begin{tabular}{llll}
\hline & \multicolumn{3}{c}{ Hazard } \\
\cline { 2 - 4 } Damage & P3 & P2 & P1 \\
\hline D4 & R4 & R3 & R2 \\
D3 & R3 & R3 & R1 \\
D2 & R2 & R2 & R1 \\
D1 & R1 & R1 & R1 \\
\hline
\end{tabular}

results of both methodologies are those designed for the 1in-10- and 1-in-100-year return period events.

\section{Results}

This section is split into two subsections, as for the Methods section. The comparison between the results of the two methodologies and the qualitative validation of the maps is presented.

\subsection{Vulnerability maps along profile lines}

The comparison between the obtained TWLs, along each profile line and for each scenario, and the location of artificial structures or dunes located along the same profiles lead to the definition of nine typologies of impact with one typology that defines a safe-from-inundation/damage condition (Ciavola et al., 2008; Armaroli et al., 2012a; Fig. 3). A symbol was assigned to each typology in order to represent the results in a GIS-based program.

In summary, it is important to outline that the coast is vulnerable to storms with a high probability of occurrence (1in-1-year return period event) because almost $60 \%$ of the analysed transects fall under one of the nine typologies of impact. If we take into account the 1-in-10-year return period scenario, the amount of vulnerable profiles increases to $80 \%$.

A first comparison between the vulnerability maps and the impact of storms was carried out taking into account a major event that occurred on 10 March 2010. The storm was close to a 1-in-5-year return period event and characterised by 


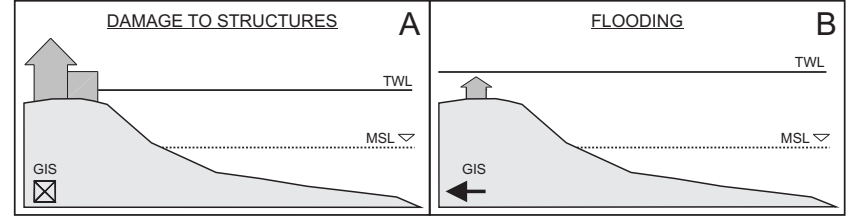

Figure 3. The two typologies of vulnerability along profile lines cited in the text and the corresponding GIS symbol (lower left corner of each schematic). (a) Damage to structures and (b) flooding. For the remaining seven typologies, refer to Ciavola et al. (2008) and Armaroli et al. (2012a).

Table 4. Flood-prone surface in terms of incremental surface (additional flood-prone surface of each scenario with respect to the previous one(s)) and total inundated surface.

\begin{tabular}{lcc}
\hline Scenario & $\begin{array}{c}\text { Incremental flood-prone } \\
\text { surface (hectares) }\end{array}$ & $\begin{array}{c}\text { Total flood-prone } \\
\text { surface (hectares) }\end{array}$ \\
\hline P3 & 1867 & 1867 \\
P2 & 1270 & 3137 \\
P1 & 4735 & 7872 \\
\hline
\end{tabular}

high surge levels (0.93 m a.m.s.l.), a wave height (Hs max) of $3.91 \mathrm{~m}$ and an associated $\mathrm{Tp}$ of $10 \mathrm{~s}$. The direction of Hs max was $59^{\circ}$ north. After the storm, the SGSS and local technical services collected information on the location of damages and flooding along the whole regional coastline. Seven areas were affected by the event (located in Ravenna, Forlì-Cesena and Rimini provinces, Fig. 1). In Fig. 4 the Lido di ClasseLido di Savio (Ravenna) example is presented in comparison to the 1-in-10-year return period vulnerability map along profile lines (Fig. 3).

The site is characterised by significant human occupation, coastal protection structures (detached shore-parallel breakwaters) and a river mouth (the Savio River). The blue areas in Fig. 4 represent the location and alongshore length (but not the landward extension) of storm consequences that are illustrated in ArcGIS ${ }^{\circledR}$ by means of polygon features. The vulnerability maps show that the profile lines that cross the damaged/flooded areas are associated with a well-defined typology of impact (Fig. 3). The same correspondence occurs along the remaining six areas identified all over the regional coast (Armaroli et al., 2012b).

\subsection{Hazard and risk maps}

The extension of flood-prone areas along the regional coastline is presented in Table 4. The values are given in terms of incremental extension of flood-prone areas (additional floodprone surface of each scenario with respect to the previous one(s)) and of the total flood-prone surface (i.e. the sum of the flood-prone surface extension of each scenario with the extension of the flood-prone surface of the previous one(s).

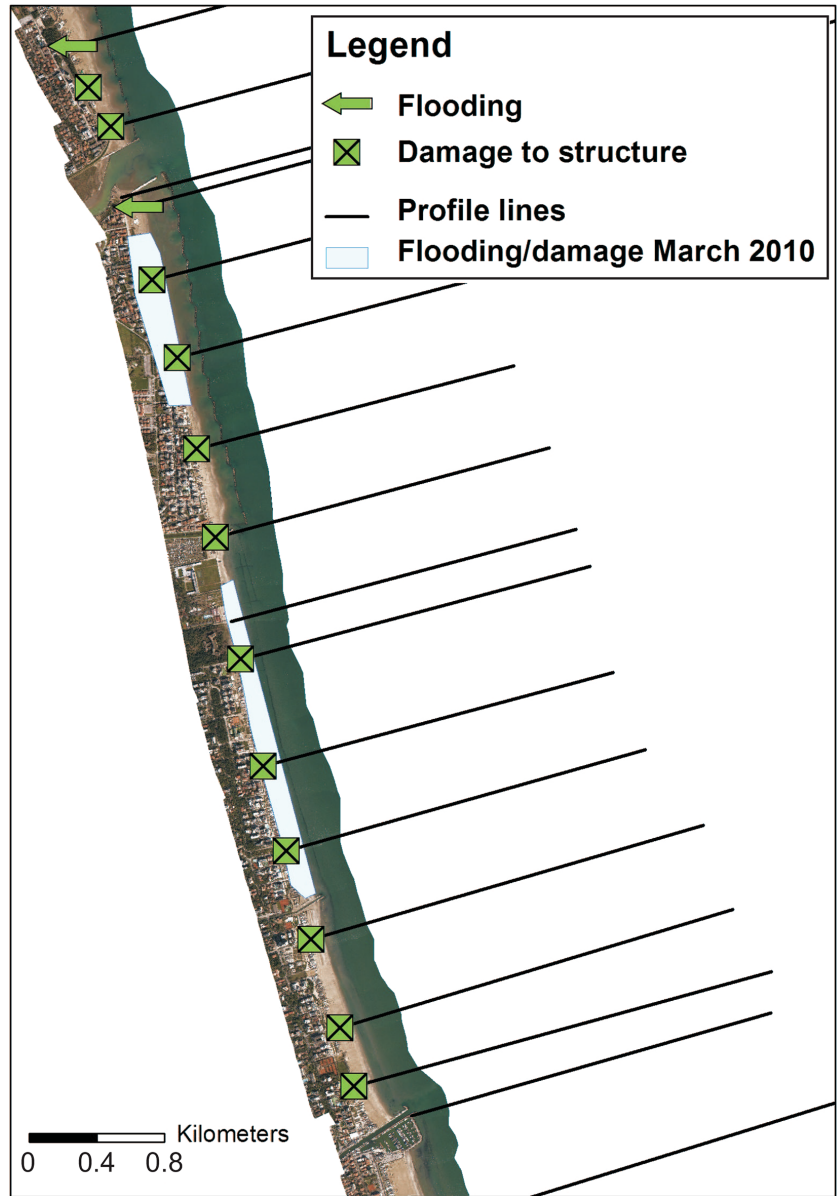

Figure 4. Location of impacts after the March 2010 storm along the Lido di Savio area and vulnerability symbology along profile lines of the 10-year return period scenario.

The most frequent event designed for the 1-in-10-year return period storm is able to inundate more than 1800 ha of the coastline. The 1-in-100 event almost doubles the flood-prone zone and the $>1$-in-100 event is 2.5 times the extension of flooded areas with respect to the P3 + P2 scenarios. The majority of the P3 extension includes the beach surface, while P2 and P1 mainly occur along urbanised areas.

\subsubsection{Viserba site}

An example of the hazard mapping is presented in Fig. $5 \mathrm{c}$ for the Viserba site (Rimini province, Fig. 5a). The site was chosen because it presents the best example of "passage" (yellow cross in Fig. 5c and d) that favours the water ingression. The given example is a road with an underpass below the railway track that is running alongshore. Thirteen passages were identified along the whole coastline, corresponding to weak points that deserve to be given special attention. In Fig. 5b, land use typologies and sensitive structures, such as hospitals and health care structures, schools, water and elec- 

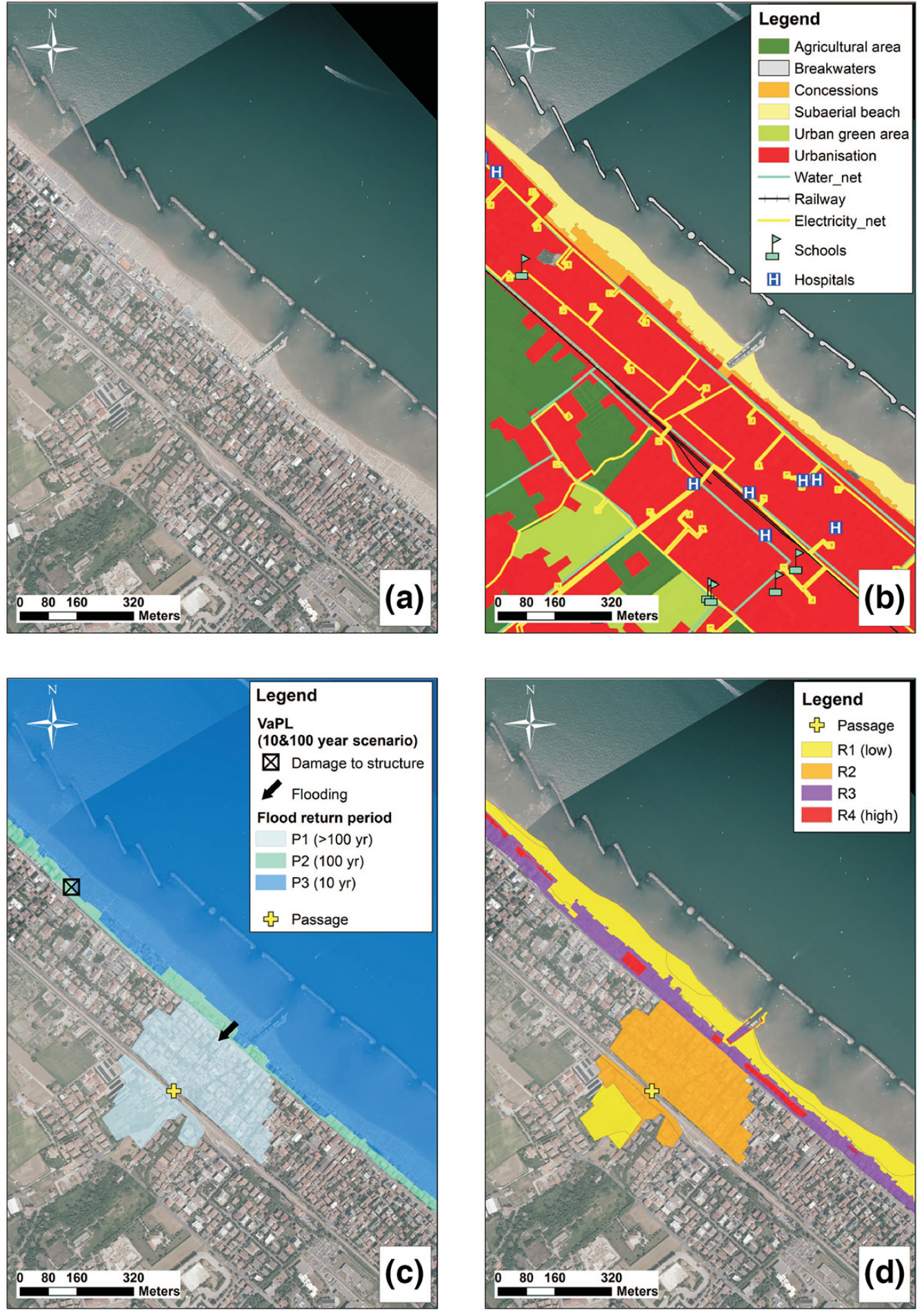

Figure 5. The Viserba, Rimini province, site. (a) 2005 aerial photograph of the area (AGEA flight), (b) land use map and sensitive structures, (c) hazard map, and (d) risk map. The symbols in panel (c) represent the vulnerability typologies of the 10- and 100-year return period scenarios. The yellow cross represents the location of a low-lying passage. 
tricity networks and the railway, are presented. The figure shows that the area is mostly occupied by urban buildings, while the beach is protected by shore-parallel breakwaters (Fig. 5a). Risk maps were created through a GIS-based program (Fig. 5d). The beach area is mapped as low risk (R1), as well as the fields located in the hinterland, while structures and human-related activities are considered R3 and R4 risks, i.e. the highest levels. R3 corresponds to areas occupied by buildings and infrastructures (land use typologies: "bathing establishments" and "urbanisation") that resulted as flood-prone under medium-frequency conditions (P2); R4 is assigned to the same type of land use but which is floodprone under high-frequency conditions (P3). It is important to note that sensitive structures, such as schools and hospitals/health care structures, are not affected by flooding in this area.

The comparison between the hazard maps and the vulnerability maps along profile lines is presented in Fig. 5c. The typologies of vulnerability are "flooding" and "damage to structures" (Fig. 3). The symbols in the figure refer to the 10- and 100-year return period scenarios. In fact, for both scenarios the area shows the same vulnerability (the legend is named accordingly). The comparison between the P3 hazard scenario (10-year return period) and the VaPL mapping shows that there is full agreement along the northern profile. Along the southern profile the VaPL method predicts inundation, while the hazard cartography underlies the probable flooding of the structures located close to the beach but not of hinterland zones. If we compare the $\mathrm{P} 2$ scenario (100-year return period) with the VaPL mapping, there is complete agreement along both profiles.

\subsubsection{Lido di Classe-Lido di Savio-Cervia sites}

The hazard maps were qualitatively validated through the comparison with floods and damages measured after the 31 October-1 November 2012 storm (Harley et al., 2015), which was characterised by very high surge levels ( $1.15 \mathrm{~m}$ a.m.s.l., measured at Porto Corsini tide gauge, Ravenna, Fig. 1), between a 1-in-20- and a 1-in-50-year return period event and a significant wave height of $2.41 \mathrm{~m}$ (measured at the Cesenatico buoy, Fig. 1), slightly lower than the 1-in-1-year return period event. After the storm, the SGSS surveyed the location of flooded areas along the whole coastline and collected information on damages, beach erosion, inundation, damage to protection structures and river flooding as reported by local technical services. The surveys were carried out with an RTK-DGPS (vertical accuracy of $\pm 0.03 \mathrm{~m}$ ). The qualitative comparison is shown in Fig. 6a for the area of Lido di Classe-Lido di Savio and Cervia, Ravenna province, together with the vulnerability typologies along profile lines. The typologies, as was the case for the Viserba site, are identical between the 10- and 100-year return periods. In Fig. $6 \mathrm{~b}$ the corresponding risk map is also presented. In the northern area, the technical services reported flooding (green star in Fig. 6a), while damage to bathing establishments was observed in the southern part (red cross in Fig. 6a).

The VaPL prediction is consistent with the reported consequences of the storm. For example, the area close to the Savio River mouth (located in the northern section of the area) experienced flooding, and indeed the vulnerability typology is consistent with the observed damage. Furthermore, the field survey shows that the first line of structures located on or close to the beach experienced damage and inundation. Again, the vulnerability along profile lines is consistent. The only non-consistent result occurs in the southern area, where a large inundation was surveyed, while the symbol indicates "damage to structure".

The hazard maps issued for the Floods Directive are therefore quite consistent with the reported damages and with the post-storm survey, even if the extension of flooding is overestimated in the central part and underestimated along a limited portion of the southern zone (Fig. 6a). The comparison between the hazard maps and the VaPL mapping shows quite good agreement, especially for the P3 scenario. The P2 scenario incorporates larger portions of the hinterland, while the vulnerability symbols again indicate "damage to structures". The risk map (Fig. 6b) gives results that are similar to the Viserba ones, and the majority of the area is categorised as $\mathrm{R} 3$ and R4 risk.

\section{Discussion}

The methods used to produce the vulnerability maps along profile lines were adopted by the regional authorities 1 year before the issuing of the Floods Directive, because the coastal vulnerability to storms was already considered a priority by regional managers, due to its impact on infrastructures and population and its associated costs. The result is a clear and replicable methodology that includes diverse environments with a wide range of different characteristics. The produced maps have the potential to detect hotspots of vulnerability along the coastline. The run-up component is important to calculate a reliable total water level for each scenario and, as pointed out by Armaroli et al. (2009b), if not included in the computation, the resulting maps are significantly different from what may actually occur.

The comparison between the VaPL cartography and the location of damages to structures and flooding along the coastline, collected after the March 2010 storm, reveals that the vulnerability typologies correctly identify where the coastline is exposed to such hazards. The comparison outlines that the mapping along profiles is reliable but, on the other hand, uncovers the fact that not all the profiles categorised as highly vulnerable were actually damaged. The reason for the discrepancy could be that the March 2010 storm was less energetic than the worst-case scenario used for the comparison. Furthermore, if the designed TWL intersects the structure lo- 

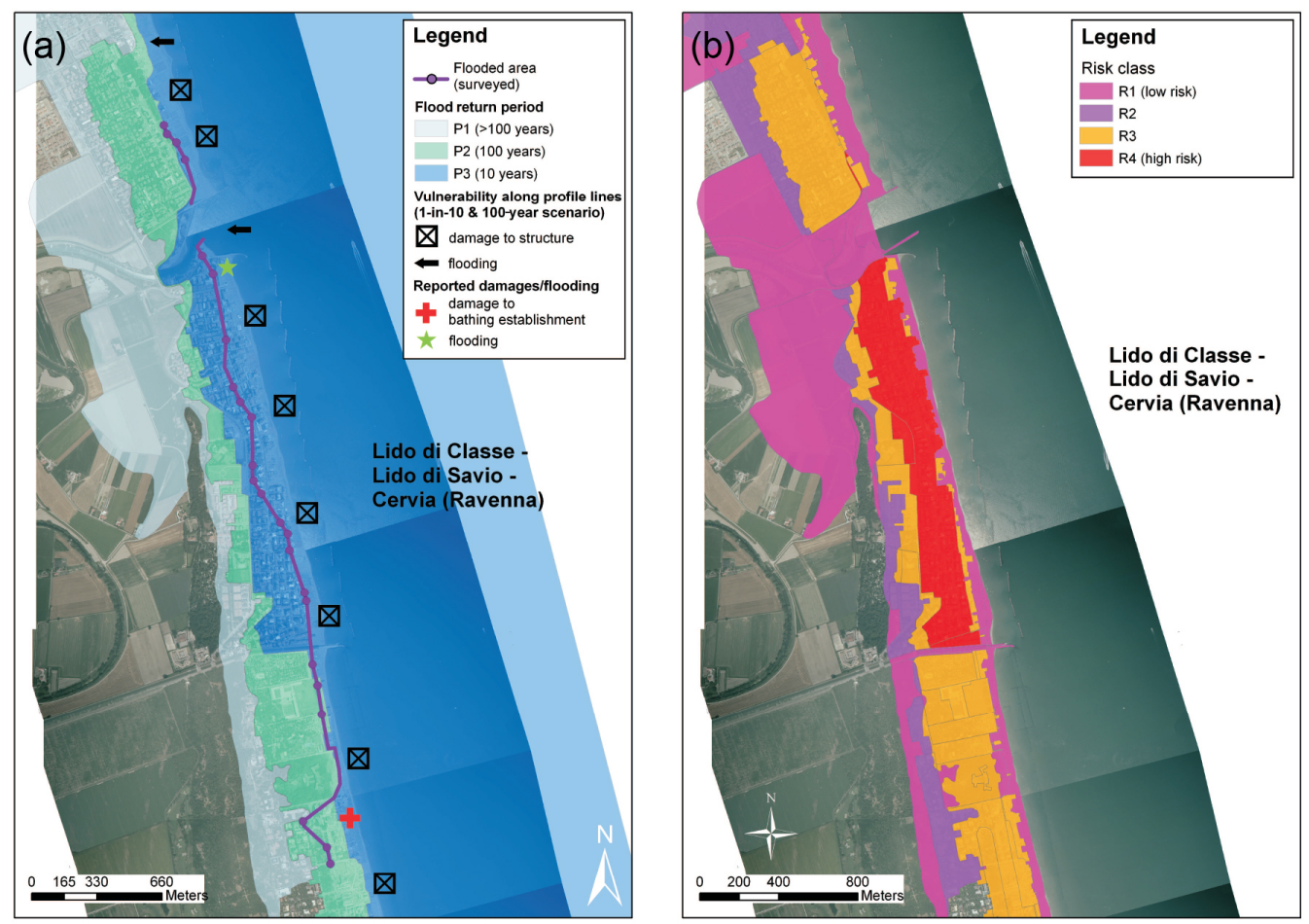

Figure 6. The Lido di Classe-Lido di Savio-Cervia sites. (a) Hazard map with post-storm survey, reported impacts and legend along profile lines of the 10- and 100-year return period scenarios. (b) Risk map.

cated along the profile, the "damage to structure" vulnerability typology is assigned (Fig. 3). However, in real conditions the water can flow around buildings and along alleys, leading to inundation of rear areas.

The hazard maps describe the areal extension of floodprone areas along the whole coastline, thus including the alongshore and landward components. The method developed for this study does not include information on soil roughness and permeability, which control flow velocity, water discharge and, ultimately, the extent of inundation. Nevertheless, the least-path calculations can be considered as a proxy for both the variables mentioned above, because the longer the path, the less probable the inundation, since increasingly higher water levels are needed to allow for flooding (Sekovski et al., 2015). Furthermore, a proper 2-D hydraulic model would be needed to compute flow velocities and water depths (Barredo et al., 2008; Wadey et al., 2012) and to consider soil roughness (Barredo et al., 2008; Zhang et al., 2008; Wadey et al., 2012; Villatoro et al., 2013). Wadey et al. (2012) found that overtopping and breaching processes (i.e. defence failure) are very important for evaluating flood hazards, but unfortunately this is a process that is rarely taken into account when flood mapping is done. Moreover, Villatoro et al. (2013) demonstrated the importance of overflow of fresh water canals and overtopping and breaching of banks (inland defences) when dealing with coastal flooding. For example, this is a process with relevance to the Comacchio mu- nicipality, in the Ferrara province (Fig. 1), and in that case it should be accounted for if detailed flood risk mapping needs to be done.

Poulter and Halpin (2008) improved the bathtub method through the inclusion of the hydrological connectivity among adjacent cells. In the procedure presented in our paper, a sort of hydrological connectivity method is used to remove isolated areas from the polygon feature derived at the end of the model chain, even if the procedure is applied by means of a simple spatial analysis of the geometrical connectivity between the source (the shoreline) and each flood-prone polygon. Despite its limitations, the procedure is more reliable than the bathtub method and uses a highly detailed DEM, without the need to lower the resolution, as would occur if a computationally efficient hydraulic model were to be applied. Gallien et al. (2011) found that, for protected urban areas, hydraulic models outperform equilibrium flood-mapping methodologies, which ignore hydraulic connectivity and are strongly biased towards overprediction of flood extent. However, infrastructure geometry data including flood defences, street and parcel elevations are crucial for accurate flood prediction. Through comparison between model grids based on GPS-RTK surveys (RMSE of $\sim 1 \mathrm{~cm}$ ) and an aerial lidar (RMSE of $\sim 15 \mathrm{~cm}$ ), the authors found that the latter was not accurate enough when used for a hydraulic model, which required high details of elevation for flood protection structures. Considering the computational 
requirements that even a 2-D hydraulic model has, and the impossibility of implementing it for long stretches of coastlines at a meaningful resolution, the methodology we propose is a good trade-off between the hydraulic and the bathtub approach.

Similar to other simplified methods and numerical models, the described method does not take into account beach and dune erosion even if they are important morphological processes during a storm. This issue has been extensively discussed by Ciavola et al. (2014) for the applicability of numerical tools (XBeach) within early warning systems for predicting storm impacts. For operational tools, the current state of the art highly recommends numerical models. For a strategic flood-mapping exercise the assumptions presented here may be enough for a rough estimation of dune overtopping. However, it is recommended that more detailed numerical approaches be undertaken (e.g. Harley et al., 2011) to assess whether the sediment reservoir within the dune provides enough protection during the storm. Furthermore, a more detailed numerical approach should also consider the effect of storm clusters on the dune/beach system that can lead to the formation of passages of inland flows (e.g. dune breaching), aggravating the inundation extent (Ferreira, 2005; Vousdoukas et al., 2012; Karunarathna et al., 2014; Dissanayake et al., 2015).

Finally, the over/underestimation of flood's extension could be due to the exclusion of run-up values and to the difference between the scenarios used for the evaluation and the observed storms, in addition to local variability in storm surge levels between different locations. One should remember that the statistics used for the return period water levels are based on the tide gauge located in Ravenna, and recent studies in the North Sea have identified the importance of local variability through field mapping of water levels after a major surge (Spencer et al., 2014). Breilh et al. (2013) reanalysed the forcing components and surge levels generated by storm Xynthia by coupling the SELFE model (Zhang and Baptista, 2008) and the WaveWatch III model (Tolman, 2009) following the methodology presented in Bertin et al. (2012). The authors found that the difference in surge levels along the coastal area of the Atlantic coast of France, northward of the Gironde Estuary, was up to $1 \mathrm{~m}$ (from $4 \mathrm{~m}$ NGF (Nivellement Général de la France) in the southern part of the study area to almost $5 \mathrm{~m}$ NGF in the northern one). The sea level rise (SLR) component was not taken into account in this study. A careful estimation of SLR projections for the Adriatic Sea is not yet available and global/Mediterranean projections are probably not representative of what might occur in the enclosed basin of the northern Adriatic area. Nevertheless, the results presented in this paper are promising, as the comparison demonstrates the good agreement between the observed impact and the predicted ones. Regional managers and decision makers are aware that the maps need to be improved; this is the reason why a re-computation of run-up values with more recent topographic data sets is planned for the future.

The results of marine flood hazard mapping, based on different numerical and/or more simplified approaches, are generally not tested against information surveyed after a storm or reported damages. Bertin et al. (2014) present a comparison, along a large tract of the central Bay of Biscay on the Atlantic coast of France, between the measured flooding extension after the 2010 storm Xynthia and the modelled inundation. The overall agreement between the predicted vs. modelled flooded areas is reasonable, but the model overpredicts the flooding extension on large marshes, while it fails to represent the inundation of small marshes located along the coastline. The overestimation is explained by the low spatial resolution of the grid used to properly represent small topographic features, while the non-prediction of flooding is explained by the exclusion of infragravity waves and run-up levels within the modelling system. The authors state that increasing the grid resolution to include small-scale features would increase the size of the grid and the subsequent computational time significantly. In the present paper, a qualitative validation of flood hazard maps represents, to our knowledge, the first evaluation of the reliability of the maps produced in Italy for the Floods Directive. If all the available information is put together (post-storm surveys and reported impacts), the results are consistent. The comparison between the two methodologies, even though there is a difference in the approach (vulnerability along profiles vs. hazard and risk) and the designed scenarios, underlines that the procedure adopted by the Emilia-Romagna region to assess the location of vulnerable spots is consistent with the results obtained to fulfil the directive's requirements and is a valuable tool to understand coastal dynamics in the framework of flood impacts. The robustness of both approaches derives from the rigorous evaluation of the information collected on past and recent storms and their consequences, from the large amount of data collected on coastline characteristics and from the close link between the central regional authorities with their peripheral offices, who have the task of carrying out postevent assessments. The qualitative comparison between the obtained maps and post-storm surveys is being updated after every significant storm, and the SGSS continues to undertake post-storm surveys and collect information from peripheral services on storm impact. The recording of post-storm data is a fundamental activity for improving the methodology and identifying if, where and why the issued maps fail or are able to represent a true risk condition.

\section{Conclusions}

In Europe, the evaluation of coastal flooding has become a high priority, since the implementation of the Floods Directive is required by all member states. The directive entered into force in 2007, and by the end of 2011 a preliminary 
flood risk assessment had to be produced for all coastal areas in the European Union. Most countries had no experience in coastal flood mapping, and in some cases there was a scarcity of the data required (e.g. high-resolution topography, characterisation of wave and tide forcing, probabilistic analyses of events). Practitioners were asked to produce the flood maps within a limited time and therefore simple methods were to be implemented, available from data-rich sites as well from sites where only a rough assessment could be made.

The methodologies presented in this paper have produced important results for the evaluation of flood risk along one of the most developed coastal regions in the Mediterranean. The fact that the methods were qualitatively validated through the analysis of real cases provides robustness compared to purely theoretical approaches, based only on probabilistic considerations. The most important source of information to assess the reliability of the evaluations was an in-depth knowledge of the coastal territory, which has been developed by the leading end user (SGSS) in the region. A good knowledge of historical and more recent landscape evolution, as well as the availability of a database of historical information on extreme events and their consequences, has provided test data for the flooding assessments. Thus, the large number of data sets used to implement and test both methodologies described in the current paper confirms that they are robust and provide reliable results.

Both approaches used in this paper are strictly dependant on the quality of the marine forcing parameters used for the evaluation. Return periods were obtained from literature sources that need updating, and the wave and surge components were treated separately, although a joint probability may occur. The SGSS will improve the methodology developed so far by updating the analysed return periods with more recent data sets and evaluating the combined probability of occurrence of storms and surge levels. However, this was not feasible within the timescale set by the EU directive (i.e. slightly more than 1 year, considering the first guidelines issued in 2012 by the Ministry of the Environment on the application of the directive in Italy).

One of the most important outcomes of the present work is related to the resolution and accuracy of DEMs in controlling the quality of flooding assessments. A high-resolution analysis is fundamental for taking into account micro-topographic variations and the presence of human structures, especially in highly developed areas such as urban ones. The positions of passages that favour landward flows were detected only because a high-resolution DEM was used. They are considered as weak points along the coastline that need to be given special attention as they act as preferential routes for flooding. The SGSS is carrying out a detailed analysis of surveyed storm impacts to determine whether the identified passages have in reality acted as preferential paths during recent events.

The risk maps developed with the cost-distance method identified that areas along the coastline where flood de- fence structures are located (artificial embankment, dykes, rubble-mound slopes), e.g. in the Ferrara littoral, were more resilient, compared to others where the only defences are wave-dissipating structures (e.g. breakwaters). However, in the evaluation carried out through the VaPL method, only overtopping was considered in the case of dyke and rubblemound slopes, but not structural failures. These aspects deserve further investigation, as does the computation of overtopping discharge, as this will control the quantity of water flowing landward.

The two methods used for this study have provided critical strategic information that could be used in the future to design effective integrated strategies and to improve future coastal planning. The coastal area of Emilia-Romagna is indeed under considerable pressure from urban development. Ideally, the methods could be used for developing setback criteria for decreasing risk (Nordstrom et al., 2015), coupling the analysis with a full cost-benefit economic evaluation of adaptation measures. Finally, the method can be applied to any other area exposed to risk from marine flooding because of its simplicity and low demand for computational resources. The only limit remains the availability of good topographical and hydraulic information.

Author contributions. L. Perini and L. Calabrese designed, implemented and refined the methodology adopted to produce hazard maps. G. Salerno built the model into ArcGIS ${ }^{\circledR}$ and developed the code. P. Ciavola and C. Armaroli designed, implemented and tested the methodology of the vulnerability along profile lines in close cooperation with L. Perini and L. Calabrese. C. Armaroli prepared the manuscript with contributions from all co-authors, prepared the figures and made the comparison between the two methodologies and the surveyed data.

Acknowledgements. C. Armaroli and P. Ciavola acknowledge the support of the RISC-KIT project (EU contract 603458, details at www.risckit.eu). The authors are grateful to P. Luciani of SGSS for the field surveys and GIS support.

Edited by: J. Brown

Reviewed by: four anonymous referees

\section{References}

Armaroli, C. and Perini, L.: A simplified methodology for the estimation of wave runup on armoured rubble slopes for vulnerability assessment, in: Proceedings of 7th Euregeo Conference, I, Bologna, Italy, 12-15 June 2012, 355-356, 2012.

Armaroli, C., Ciavola, P., and Masina, M.: Morphological thresholds for the definition of the vulnerability of coastal dunes in northern Italy, in: Proceedings of AGU Conference, 90(52), EOS Transaction. AGU, San Francisco, California, 14-18 December 2009, 2009a. 
Armaroli, C., Ciavola, P., Masina, M., and Perini, L.: Run-up computation behind emerged breakwaters for marine storm risk assessment, J. Coastal Res, SI 56, 1612-1616, 2009 b.

Armaroli, C., Ciavola, P., Perini, L., Calabrese, L., Lorito, S., Valentini, A., and Masina, M.: Critical storm thresholds for significant morphological changes and damage along the EmiliaRomagna coastline, Italy, Geomorphology, 143-144, 34-51, doi:10.1016/j.geomorph.2011.09.006, 2012a.

Armaroli, C., Perini, L., Calabrese, L., Luciani, P., Salerno, G., and Ciavola, P.: Cartografia di rischio da mareggiata della fascia costiera della Regione Emilia-Romagna, in: Proceedings of Meeting Marino, edited by: D'angelo, S. and Fiorentino, A., ISPRA, Roma, 25-26 October 2012, ISBN 978-88-448-0587-6, 25-33, 2012b.

Armaroli, C., Grottoli, E., Harley, M. D., and Ciavola, P.: Beach morphodynamics and types of foredune erosion generated by storms along the Emilia-Romagna coastline, Italy, Geomorphology, 199, 22-35, doi:10.1016/j.geomorph.2013.04.034, 2013.

Barredo, J. I., Salamon, P., and Bódis, K.: Towards an assessment of coastal flood damage potential in Europe, European Commission, Joint Research Centre (JRC) and Institute for Environment and Sustainability (IES), EUR 23698 EN, ISSN 1018-5593, 2008.

Bertin, X., Bruneau, N., Breilh, J.-F., Fortunato, A. B., and Karpytchev, M.: Importance of wave age and resonance in storm surges: The case Xynthia, Bay of Biscay, Ocean Model., 42, 1630, doi:10.1016/j.ocemod.2011.11.001, 2012.

Bertin, X., Li, K., Roland, A., Zhang, Y. J., Breilh, J.-F., and Chaumillon, E.: A modeling-based analysis of the flooding associated with Xynthia, central Bay of Biscay, Coast. Eng., 94, 80-89, doi:10.1016/j.coastaleng.2014.08.013, 2014.

Breilh, J. F., Chaumillon, E., Bertin, X., and Gravelle, M.: Assessment of static flood modeling techniques: application to contrasting marshes flooded during Xynthia (western France), Nat. Hazards Earth Syst. Sci., 13, 1595-1612, doi:10.5194/nhess-131595-2013, 2013.

Ciavola, P., Armaroli, C., Chiggiato, J., Valentini, A., Deserti, M., Perini, L., and Luciani, P.: Impact of storms along the coastline of Emilia-Romagna: the morphological signature on the Ravenna coastline (Italy), J. Coastal Res., SI 50, 540-544, 2007.

Ciavola, P., Armaroli, C., Perini, L., and Luciani, P.: Evaluation of maximum storm wave run-up and surges along the EmiliaRomagna coastline (NE Italy): A step towards a risk zonation in support of local CZM strategies, In: Integrated Coastal Zone Management - The Global Challenge, Research Publishing Services, Singapore, 505-516, 2008.

Ciavola, P., Ferreira, O., Van Dongeren, A., Van Thiel de Vries, J., Armaroli, C., and Harley, M.: Prediction of Storm Impacts on Beach and Dune Systems, in: Hydrometeorological Hazards: Interfacing Science and Policy, 1, Chapter: Prediction of Storm Impacts on Beach and Dune Systems, Wiley Publications, edited by: Quevauviller, P., 227-252, 2014.

Colle, B. A., Buonaiuto, F., Bowman, M. J., Wilson, R. E., Flood, R., Hunter, R., Mintz, A., and Hill, D.: New York City's Vulnerability to Coastal Flooding, B. Am. Meteorol. Soc., 89, 829-841, 2008.

Corbella, S. and Stretch, D. D.: Multivariate return periods of sea storms for coastal erosion risk assessment, Nat. Hazards
Earth Syst. Sci., 12, 2699-2708, doi:10.5194/nhess-12-26992012, 2012.

CREW - Centre of Expertise for Waters: Coastal Flooding in Scotland, A guidance document for coastal practitioners, CREW, The James Hutton Institute and Scottish Government, 74 pp., available at: http://www.crew.ac.uk/sites/www.crew.ac.uk/ files/publications/coastal_flooding_in_scotland.pdf (last access: 18 December 2015), 2012.

Decouttere, C., De Backer, K, Monbaliu, J., and Berlamont, J.: Storm wave simulation in the Adriatic Sea, in: CENAS - Coastline Evolution of the Upper Adriatic Sea due to Sea Level Rise and Natural and Anthropogenic Land Subsidence, edited by: Gambolati, G., Kluwer Academic Publishers, 28, 185-205, 1998.

de Moel, H., van Alphen, J., and Aerts, J. C. J. H.: Flood maps in Europe - methods, availability and use, Nat. Hazards Earth Syst. Sci., 9, 289-301, doi:10.5194/nhess-9-289-2009, 2009.

Dissanayake, P., Brown, J., Wisse, P., and Karunarathna, H.: Comparison of storm cluster vs isolated event impacts on beach/dune morphodynamics, Estuar. Coast. Shelf S., 164, 301312, doi:10.1016/j.ecss.2015.07.040, 2015.

EXCIMAP, European exchange circle on flood mapping: Handbook on good practices for flood mapping in Europe, EXCIMAP, 60 pp., available at: http://ec.europa.eu/environment/water/ flood_risk/flood_atlas/pdf/handbook_goodpractice.pdf (last access: 18 December 2015), 2007.

Ferreira, O.: Storm groups versus extreme single storms: predicted erosion and management consequences, J. Coastal Res., SI 42, 221-227, 2005.

Gallien, W., Schubert, J. E., and Sanders, B. F.: Predicting tidal flooding of urbanized embayments: a modeling framework and data requirements, Coast. Eng., 58, 567-577, 2011.

Gesch, D. B.: Analysis of Lidar Elevation Data for Improved Identification and Delineation of Lands Vulnerable to Sea-Level Rise, J. Coastal Res., SI 53, 49-58, 2009.

Harley, M., Armaroli, C., and Ciavola, P.: Evaluation of XBeach predictions for a real-time warning system in Emilia-Romagna, Northern Italy, J. Coastal Res., SI 64, 1861-1865, 2011.

Harley, M. D. and Ciavola, P.: Managing local coastal inundation risk using real-time forecasts and artificial dune placements, Coast. Eng., 77, 77-90, doi:10.1016/j.coastaleng.2013.02.006, 2013.

Harley, M. D., Turner, I. L., Short, A. D., and Ranasinghe, R.: Interannual variability and controls of the Sydney wave climate, Int J. Climatol., 30, 1322-1335, 2010.

Harley, M. D., Valentini, A., Armaroli, C., Perini, L., Calabrese, L., and Ciavola, P.: Can an early warning system help minimize the impacts of coastal storms? A case study of the 2012 Halloween storm, Northern Italy, Nat. Hazards Earth Syst. Sci. Discuss., 3, 3409-3448, doi:10.5194/nhessd-3-3409-2015, 2015.

Holman, R. A.: Extreme value statistics for wave run-up on a natural beach, Coast. Eng., 9, 477-491, 1986.

Idroser: Piano progettuale per la difesa della costa EmilianoRomagnola - Aspetti meteomarini e determinazione del trasporto litoraneo, vol. III, Regione Emilia-Romagna, 57 pp., 1982.

Idroser: Progetto di Piano per la difesa del mare e la riqualificazione ambientale del litorale della Regione Emilia-Romagna, Regione Emilia-Romagna, Bologna, Italia, 365 pp., 1996. 
Jimenez, J., Kortenhaus, A., Anhalt, M., Plogmeier, C., Prinos, P., and Sulisz, W.: Guidelines on Coastal Flood Hazard Mapping, FLOODsite Report, T03-08-02, 57 pp., available at: http://www.floodsite.net/html/partner_area/project_docs/T03_ 08_02_coastal_flood_mapping_D03_1_V3_1_p01.pdf (last access: 18 December 2015), 2008.

Karunarathna, H., Douglas Pender, D., Ranasinghe, R., Short, A. D., and Reeve, D. E.: The effect of storm clustering on beach profile variability, Mar. Geol., 348, 103-112, doi:10.1016/j.margeo.2013.12.007, 2014.

Komar, P. D.: Beach Processes and Sedimentation, 2nd Edn., Prentice Hall, 544 pp., 1998.

LAWA - German Working Group on Water Issues of the Federal States and the Federal Government: Recommendations for the Establishment of Flood Hazard Maps and Flood Risk Maps, LAWA, 37 pp., Dresden, Germany, 25-26 March 2010, available at: http://www.lawa.de/documents/LAWA_HWGK15062010_ Text_Germany_ENG_f72_4d8.pdf (last access: 18 December 2015), 2010.

Lin, N., Emanuel, K. A., Smith, J. A., and Vanmarcke E.: Risk assessment of hurricane storm surge for New York City, J. Geophys. Res., 115, D18121, doi:10.1029/2009JD013630, 2010.

Masina, M. and Ciavola, P.: Analisi dei livelli marini estremi e delle acque alte lungo il litorale ravennate, Studi Costieri, 18, 87-101, 2011.

Murdukhayeva, A., August, P., Bradley, M., LaBash, C., and Shaw, N.: Assessment of Inundation Risk from Sea Level Rise and Storm Surge in Northeastern Coastal National Parks, J. Coastal Res., 29, 1-16, 2013.

NOAA - National Oceanic and Atmospheric Administration (NOAA), Coastal Services Center: Mapping Coastal Inundation Primer, NOAA Coastal Services Center, 28 pp., available at: http://coast.noaa.gov/digitalcoast/_pdf/guidebook.pdf (last access: 18 December 2015), 2012.

Nordstrom, K. F., Armaroli, C., Jackson, N. L., and Ciavola, P.: Opportunities and constraints for managed retreat on exposed sandy shores: Examples from Emilia-Romagna, Italy, Ocean Coast Manage., 104, 11-21, 0964-5691, doi:10.1016/j.ocecoaman.2014.11.010, 2015.

Perini, L., Calabrese, L., Deserti, M., Valentini, A., Ciavola, P., and Armaroli, C.: Le mareggiate e gli impatti sulla costa in EmiliaRomagna 1946-2010, Arpa Emilia-Romagna, Bologna, 143 pp., 2011.

Poulter, B. and Halpin, P. N.: Raster modelling of coastal flooding from sea-level rise, Int. J. Geog. Inf. Sci., 22, 167-182, 2008.

Purvis, M. J., Bates, P. D., and Hayes, C. M.: A probabilistic methodology to estimate future coastal flood risk due to sea level rise, Coast. Eng., 55, 1062-1073, 2008.

Quevauviller, P.: Adapting to climate change: reducing waterrelated risks in Europe - EU policy and research considerations, Environ. Sci. Policy, 14, 722-729, 2011.

Regione Emilia-Romagna, Servizio Geologico Sismico e dei Suoli: Il sistema mare-costa dell'Emilia-Romagna, edited by: Perini, L. and Calabrese, L., Pendragon Monographies, Bologna, 240 pp., 2010.

Salecker, D., Gruhn, A., Schlamkow C., and Fröhle, P.: Statistical analysis of hydrodynamic impacts for risk assessment of coastal areas, J. Coastal Res., SI 64, 1906-1910, 2011.
Sekovski, I., Armaroli, C., Calabrese, L., Mancini, F., Stecchi, F., and Perini, L.: Coupling scenarios of urban growth and flood hazards along the Emilia-Romagna coast (Italy), Nat. Hazards Earth Syst. Sci., 15, 2331-2346, doi:10.5194/nhess-15-23312015, 2015.

Spencer, T., Brooks, S. M., Möller, I., and Evans, B. R.: Where Local Matters: Impacts of a Major North Sea Storm Surge, Eos Trans. AGU, 95, 269, 2014.

Sto. Domingo, N. D., Paludan, B., Madsen, H., Hansen, F., and Mark, O.: Climate Change and Storm Surges: Assessing Impacts on Your Coastal City Through Mike Flood Modeling, Copenhagen, Denmark, DHI Water, Environment and Health Report, 11 pp., 2010.

Teatini, P., Ferronato, M., Gambolati, G., Bertoni, W., and Gonella, M.: A century of land subsidence in Ravenna, Italy, Environ. Geol., 47, 831-846, 2005.

Tolman, H. L.: User manual and system documentation of WAVEWATCH-IIITM version 3.14, Technical note, MMAB Contribution, 276, 2009.

Van Drie, R., Milevski, P., and Simon, M.: Assessment of sea level rise and climate change impacts using ANUGA, in: Proceedings of 19th NSW Coastal Conference, Batemans Bay, Australia, 15 pp., 2010.

Villatoro, M., Silva, R., Méndez, F. J., Zanuttigh, B., Pand, S., Trifonova, E., Losada, I. J., Izaguirre, C., Simmonds, D., Reeve, D. E., Mendoza, E., Martinelli, L., Formentin, S. M., Galiatsatou, P., and Eftimova, P.: An approach to assess flooding and erosion risk for open beaches in a changing climate, Coast. Eng., 87, 50-76, 2013.

Vousdoukas, M. I., Almeida, L. P., and Ferreira, O.: Beach erosion and recovery during consecutive storms at a steep-sloping, mesotidal beach, Earth Surf. Proc. Land., 37, 583-593, 2012.

Yu, C. S., Decouttere, C., and Berlamont, J.: Storm surge simulations in the Adriatic Sea, in: CENAS - Coastline Evolution of the Upper Adriatic Sea due to Sea Level Rise and Natural and Anthropogenic Land Subsidence, edited by: Gambolati, G., Kluwer Academic Publishers, 28, 207-232, 1998.

Wadey, M. P., Nicholls, R. J., and Hutton, C.: Coastal Flooding in the Solent: An Integrated Analysis of Defences and Inundation, Water, 4, 430-459, doi:10.3390/w4020430, 2012.

Zanuttigh, B.: Coastal flood protection: What perspective in a changing climate? The THESEUS approach, Environ. Sci. Policy, 14, 845-863, 2011.

Zanuttigh, B., Perini, L., and Mazzoli, P.: Scenarios of combined river and sea water inundation along the Adriatic Coast, in: Proceedings of 8th EGU General Assembly, Vienna, Austria, 3-8 April 2011, EGU2011-1694, 2011.

Zhang, K., Xiao, C., and Shen, J.: Comparison of the CEST and SLOSH models for storm surge flooding, J. Coastal Res., 24, 489-499, 2008.

Zhang, Y. and Baptista, A. M.: SELFE: A semi-implicit Eulerian-Lagrangian finite-element model for cross scale ocean circulation, Ocean Model., 21, 71-96, doi:10.1016/j.ocemod.2007.11.005, 2008. 